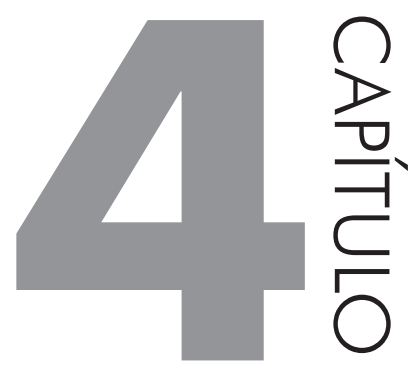

\title{
TUTORIA COMO PROCESSO DE SUPERAÇÃO
}

\section{ALUISIO CESAR BARBOSA DOS SANTOS}

\section{SÍNTESE DO PERCURSO NA TUTORIA}

Toda a experiência com Tutoria Especial Presencial começou coma minha participação na seleção disponibilizada pela Universidade Estadual da Paraíba, especificamente no curso de Licenciatura Plena em Filosofia. O cursista em destaque era um homem de 35 anos que apresentava dificuldades de aprendizagem devido a um acidente ocorrido em seu trabalho na função de policial. A experiência foi de grande aprendizagem pela relação de troca de conhecimentos e pela construção de ideias e reflexões.

Esse período durou aproximadamente dois anos. Em seguida, no decorrer de toda trajetória acadêmica, em 2015, aproximadamente no período de outubro, participo e sou aprovado na seleção para tutor presencial da UFRPE. Estou na função a mais de dois anos onde adquiri uma relação de amizade muito forte com os cursistas, contribuindo para o incentivo à permanência no curso diante das dificuldades. Dificuldades que estão sendo superadas com muita dedicação e interação entre conteúdos, cursistas e tecnologia. 


\section{RELATO DE UM FATO MARCANTE NA TUTORIA}

Há cada período cursado sempre encontramos um fato que nos direcionam para grandes reflexões e ações. Desde o início do curso as dificuldades para manter o público de forma fiel e participativo foram e estão sendo um fato marcante. A turma iniciou com 22 universitários e no decorrer da minha posse, encontrei a turma de computação com nove estudantes. Hoje a nossa turma apresenta cinco universitários matriculados e uma que concluiu o curso com outra turma anterior. Mais entre os fatos marcantes o que chamou mais a atenção foi à luta de uma das cursistas diante das dificuldades. Todos os estudantes moram em cidades vizinhas ao polo onde a dificuldade financeira e de transporte se torna um fator problemático no curso. Recordo que uma das estudantes, especificamente da cidade de Itapetim-PE, desistiu do curso por questões financeiras e familiares. Isso repercutiu de uma forma triste nos demais causando uma tristeza em todos. Diante disso, pela cooperação de todos e todas, estamos mantendo a presença desta universitária no curso com a ajuda de ambos. Outro fato marcante foi à dificuldade de um cursista de chegar a sua cidade de origem pela falta de transporte. Depois dos demais estarem em suas respectivas cidades, voltamos à noite para o polo no intuito de levá-lo a sua cidade. Lembrando que nossa cidade apresenta a distância de $35 \mathrm{~km}$ até o polo e mais uns $25 \mathrm{~km}$ até a cidade do universitário resgatado. Isso mostra a união de todos na busca do sucesso, ou seja, na conclusão de todos.

\section{MÉTODO MAIS POTENTE NO PROCESSO DE ENSINO-APRENDIZAGEM UTILIZADO COMO TUTOR}

Sabe-se que as tecnologias estão contribuindo no ensino-aprendizagem de forma muito positiva. Isso é percebido de forma clara nos cursos de educação a distância das diversas universidades no Brasil, destacando as nossas no Estado de Pernambuco. Ela tanto amplia os conhecimentos como uni pensamentos e pessoas. Assim, um método muito potente e bastante utilizado em nosso processo de ensino-aprendizagem é o programa Skype. Através dele nos comunicamos semanalmente em um grupo criado por mim, em que discutimos dificuldades e apresentamos soluções por meio de diálogos constantes sobre aquilo que foi entendido nas disciplinas e atividades selecionadas para o momento, chegando a uma solução seja verdadeira ou não. Desta forma, todos conseguem executar suas atividades, postando e ficando em dia com os prazos disponibilizados no ambiente virtual de aprendizagem do curso.

\section{NARRATIVAS DAS LIMITAÇÕES NO PROCESSO DE TUTORIA}

Todo curso, seja presencial ou a distância, apresenta grandes limitações. Dificuldades que com organização e planejamento podem ser superadas. Entre es- 
sas, aqui no polo de educação de Tabira-PE, encontramos algumas em processo de superação: i) o problema com água, e infraestrutura adequada para as necessidades dos diversos cursos, ii) disponibilidade de recursos para postagens de correspondências, como documentos e provas, e iii) da falta de uma impressora. Outra limitação bastante presente nos cursos é um retorno das correções das atividades e provas (feedback dos professores), para que cada cursista possa analisar os erros e os acertos em cada atividade.

\section{PERSPECTIVA DA TUTORIA COMO PROJETO EDUCACIONAL}

As perspectivas para um maior sucesso no curso e na conclusão de todos seriam a avalição e a construção de planos de trabalho para a melhoria constante da aprendizagem e da permanência no curso. A exemplo disso destacarei o construído para este ano (objetivos, atividades, estratégias e tarefas rotineiras). Destacando que o plano de trabalho está sujeito a mudanças a partir de avaliação no decorrer das etapas executadas.

O Plano de Tutoria Presencial se objetivaria em: i) acompanhar a frequência e realização das atividades dos cursistas no ambiente virtual, Moodle, e em momentos de encontros presenciais no polo; e ii) incentivar a permanência dos cursistas no curso no qual se encontra matriculado por meio de contribuições com dúvidas na realização das atividades.

As atividades dos alunos nas disciplinas seriam: i) encontros presenciais para estudo em grupo e resolução de dúvidas; ii) pesquisa em grupo de vídeos relacionados com os conteúdos em dificuldade e em estudo; e iii) execução das atividades propostas pelo ambiente virtual de aprendizagem.

As estratégias para o trabalho de Tutoria seriam: i) levantamento de conteúdos e dicas por atividades semanais nas respectivas disciplinas do período em estudo; ii) pesquisa artigo e vídeos relacionados ao conteúdo; e iii) uso das ferramentas tecnológicas como socialização do entendimento de cada cursista sobre o conteúdo e atividade em estudo para a sua finalização e postagem.

As tarefas rotineiras semanais do Tutor seriam: i) listar se os cursistas que não estão acessando o ambiente; ii) listar os alunos que apresentam atividades em atrasos; iii) apontar os prazos máximos para as postagens das atividades; iv) rever os conteúdos que necessitam de texto ou vídeo extra para seu entendimento; v) fazer o levantamento e o preenchimento de documentos que necessitam do seu envio com urgência; e vi) organizar as atividades presenciais. 
